\title{
Kingdom, covenant, and human rights
}

Author:
Koos Vorster ${ }^{1}$
Affiliation:
'Unit for Reformational
Studies, North-West
University, Potchefstroom
Campus, South Africa
Corresponding author:
Koos Vorster,
editor@inluceverbi.org.za
Dates:
Received: 23 Mar. 2017
Accepted: 12 May 2017
Published: 19 July 2017
How to cite this article:
Vorster, K., 2017, 'Kingdom,
covenant, and human rights',
In die Skriflig 51(2), a2257.
mobile device
to read online.
v51i2.2257
Copyright:
Q 2017 . The Authors.
Licensee: AOSIS. This work
is licensed under the
Creative Commons
Attribution License.

This research revisits the idea of a Christian perspective on human rights. Departing from a hermeneutics of trust, this article considers the concept of human rights from the perspective of revelation history. Revelation history departs from the consent of the parts of Scripture, irrespective of differences in dating, original languages, canonical differentiation, cultural, social and historical contexts. Scripture offers a theological unity consisting of various topics which are developed continuing and purposeful throughout the biblical revelation. Two of the major topics in Scripture as they are revealed by a revelation historical survey are the concepts kingdom of God and the covenant of God with God's people. In this article these two concepts will be used as a foundation for a Christian theory of human rights both as legal human rights and moral human rights. The central theoretical argument of this investigation is that both the concepts kingdom and covenant are essentially about justice and relationships - the justice of the kingdom and the relation between God and humankind, the relation between people and the relation between humans and creation. These relations are the essence of the rights people have, vis-à-vis the authority of the day and other people. These rights, which deal with the orderly maintenance of relationships, can be formalised in legal human rights and should be nurtured and protected by the civil authorities. Christians and churches as moral agents in society have the calling to promote the idea of human rights in constitutional democracies.

\section{Introduction ${ }^{1}$}

In the recent history of reformed theology there have been many attempts to establish a doctrine of human rights as it developed from the classic contributions of Calvin (1967), De Groot (1934; 1991) and Locke (1988), the criticism on the concept and the discourses that followed from various angles of approach (cf. Naude 2016:49 \& Vorster 2004:43). In the nineteenth and early twentieth centuries, reformed theologians and jurists were critical of the concept due to its perceived foundation in humanism and the rationalism of the Enlightenment. Reformed Christianity in Europe was entangled in an intense and serious struggle against the secularism of the Enlightenment and the French revolution and was critical of the idea of a secular state and the ethos of human rights. Furthermore, reformed churches showed very little interest in the social and political revolutions of the time. This negative approach can partly be ascribed to the ideas of the Dutch jurist Groen van Prinsterer (1806-1876), which were highly influential during this period. He founded his idea of the state in Calvin's view of theocracy. Although he propagated the freedom of the Dutch people and warned against state totalitarianism, he also cautioned against the 'tyranny of the people' (Groen Van Prinsterer 1904:14). As a result of his adherence to the idea of a theocracy, he was very critical of the concept of human rights over and against the state, as it was promoted amongst others by Hobbes (1588-1679), Locke (1632-1704) and Rousseau (1712-1788; 1904:112).

With the United Nations' formulation of the Universal Declaration of Human Rights in 1948 (UN 1995) after the atrocities of World War II, reformed theologians revisited the idea of human rights. In this respect the views in favour of a theological foundation of human dignity, human rights and constitutionalism of Barth (1886-1968; 1946); Bonhoeffer (1906-1945; 1995); Moltmann (1967 and 2012) and Stackhouse (1984) can be mentioned. Tracey (1981) examined the concept, public theology, and emphasised the social relevance of the 'public Christ' in a modern pluralist society. These views and various documents of the World Council of Churches stimulated a rigorous discourse in the reformed tradition. This discourse resulted in a more positive approach to the concept of human rights and the general idea that human rights can be justified biblically and can be introduced as an important Christian moral code in social ethics.

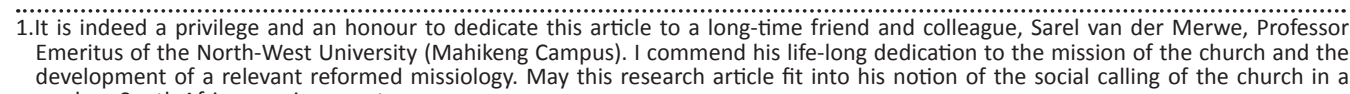
modern South African environment.

Note: This article is based on the research supported by the National Research Foundation (NRF). Any opinion, finding and conclusion or recommendation expressed in this material is that of the author and the NRF does not accept any responsibility in this regard. 
In a 2004 publication this author also endeavours to provide a biblical foundation for the concept, human rights, from a classic reformed perspective (Vorster 2004:85). With reference to various reformed ethicists and theologians such as Bonhoeffer (1906-1945; 1995) and Wüstenberg (1998), the concept of life was chosen as a paradigm for social ethics. From this angle of approach Vorster distinguished between legal human rights and moral human rights. All human rights flow from the human dignity of humankind, irrespective of its total depravity due to the fall and the all-encompassing influence of sin. Furthermore, in the mentioned publication, human rights are founded on the Ten Commandments as the other side of the coin, namely the direct obligations of each commandment. For example the obligation not to steal in the eight commandment establishes property rights and the obligation of the authority to protect the rights to private property of its citizens. The study also indicates the range of the implications of the social and ceremonial laws of the Old Testament for a modern Christian doctrine of human rights and in this process the foundational research of Braulik (1998) was utilised. In conclusion, the research focused on the responsibility of the state to nurture a relation of fairness between authorities and subjects, which can be adequately expressed in a constitutional democracy.

Recently Welker (2013:239) developed a basis for an encompassing Christian social ethics in a pluralist society by exploring the religious and social relevance of the threefold office of Christ - King, Prophet and Priest. Christ is not only the eschatological Christ, but also the public Christ. The latter is derived from the two natures of Christ. The reign of Christ is, amongst other things, characterised by a praxis of love and by the freedom mediated by that love. Christian theology should thus not only be devoted to the salvation of human beings, but also to the transformation of society according to the principle of an ethos and an institution of the love of Christ.

VanDrunen (2010) also sheds new light on relevant theological premises for a biblical social ethics in his revisiting of the concept of the two kingdoms since Calvin, and the relation of the two kingdoms with the idea of the covenant. The idea of the two kingdoms inspired churches in the tradition of the Reformation to fulfil an active social calling and to extend a prophetic voice to the fields of politics and civil society. Furthermore, the new interest of Grabill (2006) and (VanDrunen 2014) in the concept, natural law, makes possible a new vision for a Christian theory of human rights and the way Christians can deal with this contentious issue in a modern pluralist society; as well as the possibilities of cooperation with other religious traditions and civil society.

In the light of these new approaches from different angles in the reformed tradition, the author wishes to revisit his earlier stance on a Christian theory of human rights. Departing from a 'hermeneutics of trust', this article considers the concept of human rights from the perspective of revelation history. ${ }^{2}$ Revelation history departs from the consent of the parts of Scripture, irrespective of differences in dating, original languages, canonical differentiation, cultural, social and historical contexts. Scripture offers a theological unity consisting of various topics that are developed continuing and purposeful throughout the biblical revelation (cf. Barth 1932; 1961:136; Ciampa 2007:254; Cullmann 1948:157; Reuman 2005:833). This approach relates to what Van den Brink and Van der Kooi (2012:501) define as the 'theological interpretation of Scripture' - a theory of interpretation that is, in their view, growing to a productive movement in contemporary hermeneutics. A biblical scholar can therefore indeed speak of the theology of the Bible (cf. Goldingay 2006:170).

Two of the major topics in Scripture as they are revealed by a revelation historical survey, are the concepts kingdom of God and the covenant of God with God's people. In this article, these two concepts are used as a foundation for a Christian theory of human rights both as legal human rights and moral human rights. The central theoretical argument of this investigation is that both the concepts kingdom and covenant are essentially about justice and relationships - the relation between God and humankind, the relation between people and the relation between humans and creation. These relations are the essence that the rights people have, vis-à-vis the authority of the day and other people. These rights dealing with the orderly maintenance of relationships can be formalised in legal human rights and should be nurtured and protected by the civil authorities. The first topic under discussion is the concept of the kingdom of God.

\section{The kingdom of God}

The concept, kingdom of God, is an ongoing theme in the biblical revelation both in the Old and the New Testaments (Barrick 2012:190). The phrase as such does not appear in the Old Testament, but the idea is imminent. In addition, the idea does not enter the Old Testament late, but already in creation, long before the establishment of an earthly messianic kingdom (Barrick 2012:174). The fact that the idea of God's kingdom was well-known in the Old Testament is evident from the fact that John the Baptist's proclamation of the imminence of the kingdom was familiar to the Jews of his time, according to the well-known publication of Ridderbos (1962:3). In the Old Testament, Jahweh is often proclaimed as a king and this expression concerns the universal power and dominion of God over the whole world and all nations (Ridderbos 1962:4; Spiecermann 1997:123). This kingship is founded on the creation of heaven and earth. The history of the kingdom of Israel is used as a

2.The concept, hermeneutics of trust, can also be defined as a "canonical approach', This approach explains the hermeneutical theory where Scripture is professed to be the divinely inspired written Word of God with a theological unity unfolding as many the divinely inspired written Word of God with a theological unity unfolding as many themes and which is authoritative for human faith and conduct in all times and places. This theory avoids the ideas of the 'hermeneutics of suspicion' on the one hand and the mechanical or verbal inspiration (fundamentalism) on the other hand. It prefers the view that Scripture is organically inspired by the Spirit of God. Such hermeneutic acknowledges the role of literary genres and socio-historical context on the understanding of the text as useful tools, but not as presuppositions in the explication of biblical material. The text and not the history behind the text is the essential point of departure. 
historic symbol of the reign of God and God's communion with God's people. The reign of God is also an important topic in the prophetic books and wisdom literature, as is evident from Psalms 22:28; 47; 93; 96; 97; 99; 103 and 145. God is not only the God of Israel (present kingship), but of all nations and it is proclaimed as a reign that will be manifested with the coming of the Messiah (future kingship; Ridderbos 1962:6-8).

According to the research of Ridderbos (1962:9) and Napier (2016:62), the later Jewish literature (Targums) used the phrase kingdom of heaven. It denotes the moral dominium of God over humankind - a dominium that will eventually be recognised by the whole world. The concept, kingdom of God, was therefore well-known by the Jews in the time of the New Testament. The gospels use various variants of the concept such as 'kingdom of heaven' (Mt 3:2; 4:17; 11:12 and 16:19); 'kingdom of God' (Mk 1:14; 9:47; 10:24; Lk 6:20); 'kingdom' (Mt 4:23; 9:35; 13:19); and 'kingdom of the Father' (Mt 13:43; and 26:29). The phrase, kingdom of God, is also used in Acts 1:3; Romans 14:17; 1 Corinthians 4:20; Colossians 4:12. Ephesians 5:5 speaks about the 'kingdom of God and of Christ'. According to Schmidt (1969:582), these phrases all have the same meaning. It denotes the reign of God over humankind (cf. Carson 2013:199) and the consequences of this reign for human moral conduct. It is all about what God is doing and what God's subjects should be doing (cf. Napier 2016:61). The kingdom comes to people and people can come to the kingdom and eventually this reign will vindicate all earthly kingdoms and set a morality for humankind. Central to the idea of the kingdom is the cosmological salvation and renewal in Christ. Beach (2012:53) says that the coming of the kingdom brings forth not only the good message, but God's reign is a worldchanging event. It is about Christ' work of redemption from sin and reconciliation with God, but it also encompasses the fullness of human existence to bring healing and reconciliation where there is disorder, disease, brokenness and despair.

The research on the concept, kingdom of God, in recent times focuses mainly on the question whether the kingdom and its moral relevance is a future or a present reality or both? Malan (2014:1) phrases the question as such: 'The kingdom of God: utopian or existential?' The diagnosis regarding the research in this respect presented by Ladd (1961:25) a few decades ago can still be regarded as valid. In his view two main lines of thought can be distinguished. To present a view on the ethics of the kingdom, a short indication of his analysis is necessary. On the one hand the non-eschatological interpretation of Ritschl (1822-1889), Schweitzer (1875-1965) and Weiss (1863-1914) viewed the kingdom as an immanent historical reality which can and should be established by the moral actions of humans on the basis of the ethics of Christ. Influenced by the rationalism of the Enlightenment, the kingdom is not viewed as a spiritual reality of the future, but indicates a new humanity of peace and justice that can be developed in this world. This view of a realised eschatology regards the kingdom as a metaphor that describes the political task of Christianity to pursue a society of peace and justice. In this perspective the development of the doctrine of human rights as part of the Christian humanism exemplified by Christ, is high on the agenda of Christians and the Christian church. This perspective was extremely influential in the political theologies of the late twentieth century (cf. Fierro 1977). Related to the idea of the noneschatological interpretation of the concept of the kingdom of God is the theology of reconstructionism, with theonomy as its most distinctive component. Although not abandoning the eschatological interpretation altogether, this line of thought furthers the belief that biblical law, with its numerous capital offences, must be the model for Christian life and civil law (Ingersoll 2015:214). The state should be a theocracy and political planning must reflect biblical laws, especially the Ten Commandments. This idea is influential in the various factions of the so-called civil religion. ${ }^{3}$

The second line of thought distinguished by Ladd (1961:25) is the idea that the kingdom of God is a present and future reality. This idea became prominent in Protestant thought. It is what Küng (1992:56) describes as a futurist-presentist eschatology. Beach (2012:66 speaks about the Already and the Not yet of the kingdom. According to this point of view the kingdom was realised in principle with the coming and resurrection of Christ. With Christ, the kingdom has come. The reign of God over all creation was established, but the final victory of God's reign will take place with the consummation. In the meanwhile, signs of the kingdom will be erected everywhere where the name of God is confessed. The most important sign is the formation of the church with the threefold office of king, prophet and priest, like the threefold office of Christ (cf. Welker 2013:209). Furthermore, the church as the first sign of the kingdom establishes other signs of the kingdom by proclaiming in its kingly office the kingship of Christ over all creation. This entails the preaching of the norms and values of Christ with regard to science, economy, politics and culture. In its prophetic office, the church has to preach redemption, hope and peace to a broken world and society. In its priestly capacity, the church has to act as stewards of the love of Christ and manifest the attitude of servanthood amongst people. The church can thus be seen as the people of the present kingdom with the divine calling to be a prophetic, therapeutic, and moral community. Furthermore, the church should act as an example of a peaceable kingdom and a social ethics (Hauerwas 1981:72;

\footnotetext{
3.Various other variants of the concept of the kingdom of God developed throughout the history of dogma. Besides reconstructionalism, the traditional Augustinian idea that the kingdom should be identified with the church still persists (cf. Hauerwas 1981; Steinacker 1997:127). Furthermore, in some Protestant traditions the idea of the kingdom as a millennial age took root. In this respect the debate is whether the theologian should hold the view of a-millenialism, pre-millenialism or postmillenialism. In all these positions the cosmological ethical relevance of the kingdom is overlooked. Grudem (1994:1109) offers a concise explanation of these positions in his discussion of eschatology. Also worthwhile to mention is the idea of Van de Beek (2006:7), who maintains that the kingdom refers to the future dispensation Beek (2006:7), who maintains that the kingdom refers to the future dispensation and cannot be applied to define the role of theology, the church and Christians in this age. Theology should be done without an 'ulterior motive'. He grounds his point of view in the kingdom as an entirely future dispensation on the approach of the early church fathers. This investigation does not examine all these views, but focuses on the main lines of thought in the recent theology of the kingdom as these are differentiated in the work of Ladd (1961), which can still be regarded as a valid point of view.
} 
1983:99; 2001:150). ${ }^{4}$ This current investigation follows this second line of thought as it is described by Ladd.

The locus classicus of the cosmological calling of the church within the context of the present and future reign of God is Jesus' words in the sermon of the mount in Matthew 6:33. He instructs the followers to seek first of all 'his kingdom and its righteousness'. This righteousness entails the restoration of people's relation with God by way of faith in the redeeming work of the resurrected Christ, but has also ethical implications. Lus and Reumann (1997) state:

Matthew uses the term dikaiosyne to stress the ethical demand of Jesus and brings to the fore the ethical implications of the kingdom of God. Righteousness is everywhere the essence of God's salutary will, which is the community's task to do. (p. 696)

The church should therefore seek the cosmological righteousness of God and not only the soteriological. Modelled on the threefold gestalt of God's reign (Welker 2013:215), the church has to fulfil its kingly, prophetical and priestly calling to seek justice for the poor and the oppressed, peace, reconciliation and the transformation of unjust systems.

Constitutionalism with its high regard for legal fundamental human rights provides a social sphere where Christians and churches can fulfil this important calling. Protecting people against the possible power abuses of authorities on national, regional and local levels is an essential part of the seeking of the righteousness of the kingdom. So is the protection of moral and legal human rights in the social relations within a given community. The protection of human rights can be seen as a potent way in which the Christian cosmological role can be fulfilled. However, with rights come responsibilities. Christians as citizens of the kingdom have to set the example of a righteous life - a life of love, peace-seeking, reconciliation and justice. The right of the other establishes the responsibility of the self and the rights of the self establishes the responsibility of the other. Nurturing an ethos and judicial basis for the idea of human rights should be seen as an integral part of Christian social and political ethics. Indeed - Christians and churches must be the custodians of a culture of human rights.

In this process the role of civil society can also be brought into discussion. The church is per definition part of civil society. Usually civil societies are purpose-driven in order to attain

4. Hauerwas (2001:341) tends to limit the prophetic calling of the church by maintaining that the main task of the church is to act as a social ethic with an maintaining that the main task of the church is to act as a social ethic with an
alternative story. In essence, the church should act as a moral community and alternative story. In essence, the church should act as a moral community and
should be an example of a peaceable kingdom. The prime task of the church is to follow Jesus' way of life and teaching; in this way, showing the world that it is 'world'. God becomes visible through the holiness of the church; the church mus leave it to God to change the world. The heart of the church is worship. Hauerwas' emphasis on the church as an example of a peaceful alternative community is valuable and should be seen as an important aspect of the prophetic calling of the church. This idea, however, cannot comprise the sole calling of the church modelled on the threefold office of Christ. Moltmann (2012:31) criticises this deficiency of Hauerwas' view of the role of the church in society. He points out that the righteousness and justice of God in the world 'does not begin with the justification righteousness and justice of God in the world 'does not begin with the justification of the perpetrators of $\sin$; it begins with the justification of the victims of $\sin$ injustice and violence'. Justification cannot be reduced to the forgiveness of sins. Forgiveness of $\sin$ is one part of justification. The church therefore ought to protes against all forms of injustice in society. Over against the idea of Hauerwas of the church as a "peaceable kingdom,, Moltmann (2012:33) makes the case for the church as a 'peacemaking kingdom'. We are not told 'Blessed are the peaceful' but 'Blessed are the peacemakers'. some changes in society and even in government policies. On the basis of God's creational gifts of morality to all people and the responsibility of people to strive for the common good, Christians and churches can be actively involved in civil movements. Civil society has grown in strength in South Africa, and by way of public protest and utilising the constitutional court it has acted effectively as the 'watchdog' over immoral government policies and discriminatory attitudes and deeds within the broad society (cf. Vorster 2015). Seeking the justice of the kingdom needs not to be done in isolation amongst Christians and churches, but in cooperation with all other social role-players. In this way the morality of the kingdom will not only be enhanced, but will also be introduced to people who do not know God and God's kingdom. The justice of the kingdom is thus the motivating force behind a Christian advocacy of human rights and the cooperation of the church with other moral agents in the promotion of human rights.

\section{The covenant}

The concept of the covenant between God and God's people is also a prominent topic in Scripture, especially in the Old Testament literature. 'A covenant is an unchangeable, divinely imposed legal agreement between God and man that stipulates the conditions of their relationship.' (Grudem 1994:515.) This concept illustrates the self-commitment of God to the people (Perlitt 1997:710). Due to God's commitment to the people, new relations are established between God and the people and amongst the people. In his intensive study of the theology of the Old Testament, the Dutch scholar Vriezen (1962:167) indicates that the communion flowing from the covenant is the essence of biblical religion. God is seen as the God of history who exercises God's reign in and through the people. The people can know God because God reveals Himself especially to the people of the covenant. Furthermore, the covenant determines the way in which the people can express their obedience to God and it is therefore the foundation of Israel's faith and life. Covenant and conduct is closely linked.

In certain traditions of reformed theology the concept of the covenant has been developed into a paradigm for the understanding of God's actions in creation, God's relationship with humankind and eventual salvation. Grudem (1994:515) gives a résumé of this position with his discussion of the different covenants in the biblical history of salvation. This investigation does not entertain the idea of different covenants, but distinguishes between two manifestations of the one covenant between God and humankind, namely the universal covenant and the covenant of grace. These are not different covenants, but different manifestations of the one covenant signifying the development of the relation between God, humankind and creation. The one covenant is the internal basis of creation and creation is in turn the external basis of covenant (Barth 1969:42). The universal covenant (also termed the 'covenant of works', 'the covenant of nature' or 'the covenant of creation') was established by God with Adam and Eve as an expression of God's love and 
universal grace. The universal covenant with creation and humankind contains the promise of God's providence; the blessings God has given to humankind and their liberties and the responsibilities they have before God. All creation is under God's providence and humans have to execute the law given by God. This manifestation of the covenant also designates humankind's ability to do justice because of God's 'creational gifts' to humankind. God created the natural law to enable people to do God's will and to exercise their dominium over creation.

Therefore, this covenant is called the universal covenant, as Grudem (1994) formulates it:

since participation in the blessings of the covenant clearly depended on the obedience or 'works' on the part of Adam and Eve. They have no opportunity to change the details - their only choice is to keep it or break it. (p. 517)

They eventually broke it by not obeying God's demands. Is this the end of God's relation with humankind and creation? Not at all! Grudem (1994:518) acknowledges that what he calls the covenant of works is still in force in certain circumstances after the fall. This author argues that due to the fall, this manifestation of the covenant has become null and void with respect to the salvation of people and renewal of creation. Adam and Eve have indeed broken the covenant and introduced the dark age of human brokenness and the lack of ability to fulfil God's will by executing the law. ${ }^{5}$ It is no longer possible for humans to enter into a relationship with God merely on account of their obedience and moral conduct. Sin and evil distorted all relations - the relation between God and humankind, the relations between humans, and the relation between humankind and creation. As a result heretical ideologies such as atheism, racism, ethnocentrism, xenophobia, patriarchism, androcentrism, ecocide, and others entered the field of human experience. The only way of hope is a new manifestation of the covenant - the covenant of grace. This happens by way of several other manifestations of the covenant such as the Noahic, Abrahamic, Mosaic, and Davidic covenants and the covenant of redemption in Christ. However, although humankind as a whole will not in toto inherit this new covenant and its blessings and provisions, human's still have the ability and the task to make moral decisions and to struggle against injustices and broken relations on the basis of the enduring universal covenant and natural law. This is all possible due to God's enduring common grace.

The covenant of grace is a new manifestation of God's covenant with humankind. It begins with the calling of Abraham and God's promise of blessings, of which the most

5.VanDrunen (2014:481) developed a biblical theology of natural law based on the development of God's universal grace. He contends that the covenant of works is universal and is the foundation of natural law. Due to the Noahic covenant, which is ... 'a universal covenant encompassing the whole world set into place as long as the present world endures, and promising preservation of the world but not its present world endures, and promising preservation of the world but not its redemption'. This universal covenant constitutes God's dealings 'with all people as his image-bearers as those who retain their constitutive attributes and a natura moral commission to exercise (a more modest) dominium of the world' (VanDrune 2014:482). Irrespective of the breaking of the covenant of works by Adam and Eve, the commission of all people to act morally has not been repealed. God's common grace and natural law is the foundation of any moral order, but this moral order can in no way lead to the redemption of all people (cf. also Bowlin 2015:142). important is that a new nation will be formed out of the descendants of Abraham. This new manifestation of the covenant is a turning point in the redemptive history (cf. Jeon 2011:123). God will enter into a new relation with a remnant of humankind - a chosen nation. This nation will be redeemed by the Messiah. Other than the nations of the world, this nation must be a holy nation living under the reign of God and according to God's commandments. This nation is Israel. However, time and again God's people will reject the provisions of the covenant of grace. They will long to be and to act such as the nations do. They will fall into idolatry and disobedience. Therefore they will receive the punishment of God. They will eventually lose the Promised Land and will go into exile. But the covenant of grace will remain in force. The feasts, the holy places, the prophecies - even in exile, their wisdom literature preached the fulfilment of the covenant of grace in the coming of the Messiah (Vriezen 1962:475).

The coming of Christ is the visible confirmation of the covenant of grace. By way of his death and resurrection, $\mathrm{He}$ reconciles humanity with God. Where evil has a potent divisive effect, the salvation in Christ restructures broken relations - first of all the relationship with God. Humans are set in a new relationship with God, which is expressed with the metaphor of father and child. God can be worshipped as the Father. This is a deep spiritual relationship that liberates humans from the anxiety of rejection and loneliness. Through faith in Christ humans can come to God in the relationship as it was intended and created before the fall. The new covenantal relation with God extends to the marital relationship (Eph 5:21; Col 3:18-19; $1 \mathrm{Pt} \mathrm{3:1-7);} \mathrm{to} \mathrm{the} \mathrm{family}$ (Eph 6:1-4; Col 3:20-21) and labour relations (Eph 6:5-9; Col 3:22-4:1 \& 1 Pt 2:18-25). Social relations characterised by selfishness, oppression, discrimination, exploitations and other forms of hostility, due to the evil, are transformed. The covenant of grace in Christ has the hallmark of reconciliation and new relations signified by love and peace. Even the relation with the enemy is to become a relationship of love.

A prominent manifestation of the effects of the covenant of recreation is the formation of the church. The church is the people of the kingdom of God, but also the household of God. The church is a covenantal church - people coexist in a new relationship as children of God and as each other's brothers and sisters. In the world with its distorted relations, the church emerges as an example of what Hauerwas (1983) calls a peaceable kingdom. It is an alternative community that contrasts the social ills of the world (Bosch 1991; Harvie 2009:34). The church then has to act in its worship, ministry and service as a covenant community - an exemplary community testifying against all forms of oppression and discrimination.

The covenant is all about community and engagement in the formation and restoration of community in the family, the church and in society at large. It is also about the rectification of humankind's distorted relation with creation from an attitude of careless dominium to responsible stewardship. 


\section{Human rights}

How does theological concepts such as the kingdom of God and the covenant relate to a legal concept such as human rights? The point of contact is social ethics. The biblical teachings of the kingdom of God and the covenant produce a social ethic and the concept, human rights, is founded on a social ethic. The idea of inalienable human rights developed in the seventeenth century with the political thinking of John Locke (1632-1704) and his contemporaries (cf. Locke 1988). He founded his ideas both in Greek philosophy and in Christian theology. According to him, the law of nature obliges people to acknowledge the equality of all people and the obligation that no one should do harm to others. The state must execute this law of nature. Therefore, the state has no absolute power over its subjects. When the state becomes abusive or tyrannical, the subjects must have the ability and the means to replace the government with a new one and to enter into a new social contract in order to maintain a just society. A just society is where the natural rights of people are respected and protected. ${ }^{6}$

As said earlier, his ideas were not received well by churches and theologians in the reformed tradition. They were suspicious of the 'humanist nature' of human rights, which were driven by rationalism and the idea of 'natural law', in turn driven by the Enlightenment. This suspicion was furthered by the rising Orthodoxy and Pietism in Europe. Pietism and Orthodoxy in the reformed tradition in the Netherlands resulted in a critical and negative reaction to the concept of human rights as it was proposed by Locke. Calvin's social ethics and his moderate acknowledgement of rights of people were also overshadowed by this tradition's resistance to the Enlightenment. In fear of a humanist and rationalist theology, the relevance of the reformed faith for social life as stated by Calvin and his contemporaries was ignored. It is fair to state that the reformed tradition in Netherlands deviated from Calvin in favour of an orthodox and pietistic view of the reformed faith. Although neoCalvinism endeavoured to set a new paradigm for social action by Christians, this Pietism became a potent force in the development of the reformed tradition - also in South Africa.

In England and Scotland, Puritanism and Presbyterianism respectively reacted in the same way against the concept of human rights. This was also due to the spirit of Pietism and the orthodoxy of the Westminster Confession (1646). The Westminster Confession was a highly influential exposition of Calvinist orthodoxy. It became the confession of most Presbyterians, Congregationalists (with certain changes) and some Baptists in England and America. In chapter 23, this Confession expresses the same intolerance with regard to religious rights that was practised in the reformed tradition 6.For a more thorough discussion of the emergence of an ethos of human rights, see Vorster (2004:5-66) of the sixteenth century. ${ }^{7}$ The reformed tradition emphasised the authority of the civil authority to rule by divine sanction. Fundamental rights were regarded as a remnant of the humanism of the Enlightenment. This suspicion of the idea of human rights characterised reformed thinking in the eighteenth and nineteenth centuries.

The drive for the constitutional protection of human rights accelerated in the twentieth century because of the atrocities of the two world wars. It culminated in the establishment of the Universal Declaration of Human Rights by the United Nations in 1948 (UN 1948:33). Since then many countries subscribed to the Declaration and turned into constitutional democracies. South Africa followed suit in 1994. Looking at the Universal Declaration of Human Rights, it becomes clear that the aim is to promote justice and orderly peaceful relations between authorities and subjects and amongst subjects. The task of authorities is to protect the fundamental rights of citizens and to avoid the abuse of power. Constitutional courts are instituted to keep the possible abuse of power at bay.

These main aims of Bills of Human Rights coincide with main aims of the ethic of the biblical idea of the kingdom of God and the covenant. In recent years, the interest in reformed theology in the concept of the kingdom of God and the notion of 'kingdom ethics' has increased (cf. Moltmann 2012:19; Welker 2013:209). The kingdom of God is inter alia about the seeking of justice. This justice is not only about the justification and salvation of people, but the promotion of justice in the social sphere. The justice of the kingdom of God can therefore be seen as a foundation for the drive of the protection of the fundamental rights of all people. As the people of the kingdom, Christians in the capacity of their threefold office should promote the ethos of human rights and nurture a culture of human rights in societies plagued by abuse, oppression and discrimination. In this respect, constitutionalism provides a positive sphere for Christians to fulfil their calling in society as proponents of the kingdom ethics. The same applies to the church. As part of civil society and in the church and state dialogue, the church can act as the proponent of respect for human rights and as the voice of the vulnerable, the voiceless and marginalised. This important aspect of the social calling of the church needs much more attention in South Africa today. It seems that churches are more concerned about the nurturing of a pietistlike spirituality than a social concern regarding the protection of the rights of all people (cf. Olivier 2011:259).

The ethic flowing from the idea of the covenant is another potent element in the development of a Christian perspective on human rights. Human rights are all about relationships the relation between government and subject; the relations amongst people and the relation between humankind

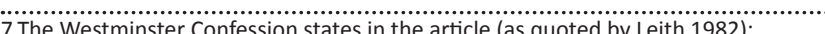
. $\ldots$ yet he (the civil magistrate) hath authority, and it is his duty to take order, that unity and peace be preserved in the church, that the truth of God be kep pure and entire, that all blasphemies and heresies be suppressed, all corruptions and abuses in worship and discipline prevented or Reformed, and all the ordinances of God duly settled, administered, and observed. (p. 220) 
and creation. The covenant is also all about relationships. First of all it deals with the rectification of the broken relationship between humankind and God. The reconciliation in Christ restores the relationship between God and humans and leads to the formation of the covenantal church - the people of God in which the nations are blessed. Of particular relevance is the view of the family as a covenant family, signified by the baptism of children and marriage as a contract before God (cf. Stackhouse 2005:153). The covenant also restores and renews the relationship between the people of God and all other people. Christians should love the enemy and do good to all people.

Furthermore, the covenant restores the relationship humankind and creation. People are called to be stewards of creation and therefore ecology should feature as a prominent topic in the Christian ethical agenda. Third generation fundamental human rights can be founded on the biblical idea of the care for nature as God's precious gift to humankind. Christian ethics should be, amongst others, an eco-ethic and the Christian church should be a custodian for the protection of nature and a strong voice against any form of ecocide.

\section{Conclusion}

Over the years reformed theology has grappled with the concept of inalienable fundamental human rights and the emerging ethos of human rights in Western thought. The idea that human rights are a remnant of the humanism of the Enlightenment still nurtures the suspicion against human rights and constitutionalism. To my mind, this suspicion was part of the reason for the quietist approach amongst reformed Christians in South Africa in the time of the ideology and policy of apartheid. The ongoing pietist spirituality in this tradition still manifests itself when it comes to the social calling of the church and the voice of Christians in civil society and in politics nowadays. It seems that churches in this tradition are more concerned about church-planting and church growth and to nurture the pietist spirituality than to enter into the human rights discourse. A thorough theological appraisal of the ethics of human rights is therefore necessary. To found a Christian perspective on human rights in human dignity and the Ten Commandments, as this author has done before (Vorster 2004:85), is not convincing enough.

This author is now of the opinion that a theology of the kingdom of God and the covenant as two major concepts in the revelation history of Scripture provides an additional and more foundational - basis for a Christian ethic of human rights. The confession of the present and future reign of God, the justice of the kingdom and its restored covenantal relation with humankind, forms the moral fibre of such an ethic. These theological concepts can urge reformed Christians and churches afresh to be the voice in society for the recognition and protection of the fundamental human rights of people and the care for the ecology. Furthermore, they should be constant companions of the governments of the day in their aim to encourage democracy and constitutionalism. Such a new theological perspective on human rights can encourage reformed Christians and churches in South Africa to act more responsibly and serious as moral agents to further human rights, democracy and peace.

\section{Acknowledgements Competing interests}

The author declares that he has no financial or personal relationships which may have inappropriately influenced him in writing this article.

\section{References}

Barrick, W.D., 2012, 'The kingdom of God in the Old Testament', The Master's Seminary Journal 23(2), 173-192.

Barth, K., 1932, Die kirchichle Dogmatik: Die Lehre vom Wort Gottes, vol. 1/1, EVZ, Zürich.

Barth, K., 1946, Christengemeinde und Bürgergemeinde, Evangelischer Verlag, Zürich.

Barth, K., 1961, Church Dogmatics, vol. IV, pt., 2, The Doctrine of Reconciliation, Clark, Edinburgh.

Barth, K., 1969, Church Dogmatics, vol. III, pt 1: The doctrine of creation, Clark, Edinburgh.

Beach, M., 2012, 'The kingdom of God: A brief exposition of its meaning and implications', Mid-American Journal of Theology 23(2012), 53-76.

Bonhoeffer, D., 1995, Ethics, Touchstone, New York.

Bosch, D.J., 1991, Transforming mission, paradigm shifts in theology of mission, Maryknoll, New York.

Bowlin, J., 2015, 'Notes on natural law and covenant', Studies in Christian Ethics 28(2), 142-149.

Braulik, G., 1998, 'Das Dt und die Menschenrechte', Theologische Quartalschrift 166, 1-17.

Calvin, J., 1967, Commentaries on the four last books of Moses, arranged in the form of a harmony, Calvin Translation Society, Edinburgh.

Carson, D.A., 2013, 'Kingdom, ethics, and individual alvation', Themelios 38(2), 197-201.

Ciampa, R.E., 2007, 'The history of redemption', in S.J. Hafemann \& P.R. House, Central themes in biblical theology: Mapping unity in diversity, pp. 254-308, Baker Academic, Grand Rapids.

Cullmann, O., 1948, Christus und die Zeit: Die uhrchristliche Zeit- und GeschichtAufassung, Evangelisher Verlag, Zurich.

De Groot, H., 1934, Verhandeling over het recht tot buit, Sijtshoof, Leiden.

De Groot, H., 1991, Denken over oorlog en vrede, Ambo, Baarn.

Fierro, A., 1977, The militant gospel: An analysis of contemporary political theologies, SCM, London.

Goldingay, J., 2006, Old Testament theology, vol. 2: Israel's faith, InterVarsity, Downers Grove.

Grabill, S.J., 2006, Rediscovering the natural law in reformed theological ethics, Eerdmans, Grand Rapids.

Groen van Prinsterer, G.G., 1904, Ongeloof en revolutie, Bos, Kampen.

Grudem, W., 1994, Systematic Theology: An introduction to biblical doctrine, InterVarsity, Leicester.

Harvie, T., 2009, Jürgen Moltmann's Ethics of hope: Eschatological possibilities for moral action, Ashgate, Surrey.

Hauerwas, S., 1981, A community of character: Towards a constructive, Christian social ethic, Notre Dame, London.

Hauerwas, S., 1983, The peaceable kingdom, University of Notre Dame Press, Notre Dame.

Hauerwas, S., 2001, 'The church as God's new language' in S. Hauerwas, The Hauerwas reader, pp. 142-162, Duke University Press, Durham.

Ingersoll, J.J., 2015, Building God's kingdom: Inside the world of Christian reconstruction, Oxford University Press, New York.

Jeon, J.K., 2011, 'The Abrahamic covenant and the kingdom of God', The Confessional Presbyterian 7(2011), 123-138.

Küng, H., 1992, The church, Burns \& Oates, Kent.

Ladd, G.E., 1961, The gospel of the kingdom of God, Eerdmans, Grand Rapids.

Leith, J.H., 1982, Creeds of the churches: A reader in Christian doctrine from the past to the present, John Knox, Atlanta.

Locke, J., 1988, Two treatises of government, Cambridge University Press, Cambridge.

Lus, U. \& Reumann, J., 1997, 'Righteousness, justice in the New Testament', in E. Fahlbusch, J.M.

Lochman, J. Mbiti, J. Pelikan \& L. Vischer, The Encyclopaedia of Christianity 4, 695-696, Brill, Leiden. 
Malan, G.J., 2014, 'The kingdom of God: Utopian or existential?', HTS Teologiese Studies/Theological studies 70(3), Art \#2109, 9 pages, https://doi.org/10.4102/ hts.v70i3.2109

Moltmann, J., 1967, Theology of hope, SCM, London.

Moltmann, J., 2012, Ethics of hope, SCM, London.

Napier, D.A., 2016, 'God in action: Jesus' gospel of the kingdom', Christian Studies 28(28), 59-72.

Naude, P., 2016, Pathways in ethics: Justice, interpretation, discourse, economics, Sun Media, Stellenbosch.

Olivier, A.R., 2011, 'Critical factors in the formalization of an apartheid theology', Studia Historiae Ecclesiasticae 28(2), 246-259.

Perlitt, L., 1997, 'Covenant', in E. Fahlbusch, J.M. Lochman, J. Mbiti, J. Pelikan \& L. Vischer, The Encyclopaedia of Christianity, 1:709-711, Brill, Leiden.

Reuman, J., 2005, 'Salvation history', in E. Fahlbusch, J.M. Lochman, J. Mbiti, J. Pelikan \& L. Vischer, The Encyclopaedia of Christianity, 4:832-836, Brill, Leiden.

Ridderbos, H., 1962, The coming of the kingdom, The Presbyterian \& Reformed Publishing, Philadelphia.

Schmidt, K.L., 1969, 'Basileia', in G. Kittel (ed.), Theological Dictionary of the New Testament, 1:579-593, Eerdmans, Grand Rapids.

Spiecermann, H., 1997, 'Kingdom of God-OT', in E. Fahlbusch, J.M. Lochman, J. Mbiti, J. Pelikan \& L. Vischer, The Encyclopaedia of Christianity 3:123-124, Brill, Leiden.

Stackhouse, M.L., 1984, Creeds society and human rights: A study in three cultures, Eerdmans, Grand Rapids.

Stackhouse, M.L., 2005, 'Covenantal marriage: Protestant views and contemporary life', in J. Witte \& E. Ellison, Covenant marriage in comparative perspective, pp. 153-181, Eerdmans, Grand Rapids.
Steinacker, P., 1997, Kingdom of God: History of theology, in E. Fahlbusch, J.M. Lochman, J. Mbiti, J. Pelikan \& L. Vischer, The Encyclopaedia of Christianity 3:127-130, Brill, Leiden.

Tracey, D., 1981, An analogical imagination: Christian theology and the culture of pluralism, Crossroad, New York.

United Nations, 1948, UN document A/REC/217 A9III, 10 December 1948, United Nations, Geneva.

United Nations, 1995, The United Nations and human rights, United Nations, New York.

Van de Beek, A., 2006, 'Religion without ulterior motive' in E.A.G.J. van der Borght, (ed.), Religion without ulterior motive, pp. 7-20, Brill, Leiden.

Van den Brink, G. \& Van der Kooi, C., 2012, Christelijke dogmatiek, Uitgeverij Boekencentrum, Zoetermeer.

VanDrunen, D., 2010, Natural law and the two kingdoms: A study in the development of reformed social thought, Eerdmans, Grand Rapids.

VanDrunen, D., 2014, Divine covenants and moral order: A biblical theology of natural law, Eerdmans, Grand Rapids.

Vorster, J.M., 2004, Ethical perspectives on human rights, Potchefstroom Theological Publications, Potchefstroom.

Vorster, J.M., 2015, 'The possible contribution of civil society in the moral edification of South African society: The example of the "United Democratic Front" and the "Treatment Action Campaign" (1983-2014)', HTS Teologiese Studies/Theological Studies 71(3), Art. \#2754, 8 pages, https://doi.org/10.4102/hts.v71i3.2754

Vriezen, T.C., 1962, Hoofdlijnen der theologie van het Oude Testament, Veenman \& Zonen, Wageningen.

Welker, M., 2013, God the revealed: Christology, Eerdmans, Grand Rapids.

Wüstenberg, R.K., 1998, A theology of life: Dierrich Bonhoeffer's religionless Christianity, Eerdmans, Grand Rapids. 